Article

\title{
Preliminary Study on Biosensor-Type Time-Temperature Integrator for Intelligent Food Packaging
}

\section{A. T. M. Mijanur Rahman, Do Hyeon Kim, Han Dong Jang, Jung Hwa Yang and Seung Ju Lee *}

\author{
Center for Intelligent Agro-Food Packaging (CIFP), Department of Food Science and Biotechnology, \\ Dongguk University, Seoul 10326, Korea; mijananftiubd@gmail.com (A.T.M.M.R.); goreh1@naver.com (D.H.K.); \\ gksehd7609@naver.com (H.D.J.); alsdn4547@naver.com (J.H.Y.) \\ * Correspondence: Lseungju@dongguk.edu; Tel.: +82-031-961-5139
}

Received: 19 May 2018; Accepted: 12 June 2018; Published: 15 June 2018

\begin{abstract}
A glucose biosensor was utilized as a platform for the time-temperature integrator (TTI), a device for intelligent food packaging. The TTI system is composed of glucose oxidase, glucose, a $\mathrm{pH}$ indicator, and a three-electrode potentiostat, which produces an electrical signal as well as color development. The reaction kinetics of these response variables were analyzed under isothermal conditions. The reaction rates of the electrical current and color changes were $0.0360 \pm 0.0020$ ( $95 \%$ confidence limit), $0.0566 \pm 0.0026,0.0716 \pm 0.0024,0.1073 \pm 0.0028 \mu \mathrm{A} / \mathrm{min}$, and $0.0187 \pm 0.0005,0.0293 \pm 0.0018,0.0363 \pm 0.0012,0.0540 \pm 0.00191 / \mathrm{min}$, at $5,15,25$, and $35^{\circ} \mathrm{C}$, respectively. The Arrhenius activation energy of the current reaction $\left(E a_{\text {current }}\right)$ was $25.0 \pm 1.6 \mathrm{~kJ} / \mathrm{mol}$ and the $\mathrm{Ea}_{\text {color }}$ of the color reactions was $24.2 \pm 0.6 \mathrm{~kJ} / \mathrm{mol}$. The similarity of these Ea shows agreement in the prediction of food qualities between the electrical signal and color development. Consequently, the function of the new time-temperature integrator system could be extended to that of a biosensor compatible with any electrical utilization equipment.
\end{abstract}

Keywords: TTI; biosensor; glucose oxidase; electrochemical reaction; intelligent food packaging

\section{Introduction}

In the course of modernization, there has been a global expansion of food distribution systems. Because the quality and safety of chilled and frozen foods are strongly influenced by temperature, the monitoring of time-temperature history throughout the entire distribution chain is necessary [1]. Commercially available monitoring devices include temperature data loggers, time-temperature integrators (TTIs), smart radio frequency identification (smart-RFID), and others. The TTI is a colorimetric label attached to food packages, which exhibits visual color changes depending on the time-temperature history, predicting the food quality status. TTIs offer several advantages over other devices, including small size, low cost, and easy operation. The TTI color change is based on physical, chemical, or biological reactions [2,3], depending on temperature [4]. The performance of TTIs for monitoring food deterioration due to the temperature abuse during the storage or distribution has been successful in many cases such as kimchi [5], frozen vegetables [6,7], fish products [8-11], meat products [12-14], mushrooms [15], and dairy products [16,17].

Unfortunately, despite longstanding recognition of TTIs as effective monitoring tools, their commercialization is still in the beginning stages. There are multiple limitations associated with time-temperature integrators such as legislative rules, accuracy, and quality indication by visible color change, among others [18,19], which are barriers to widespread adoption of this technology in cold-chain monitoring. In particular, decision-making based only on the visual observation of TTI color 
can be confusing; this hinders adoption by the food industries and acceptance by consumers. If TTI responses could be converted to digital information, that would address the problems associated with interpreting visible colorimetric information. For example, glucose-detecting redox-enzyme-based biosensors can produce an electrical current on interaction with glucose; others can change color. This raises the possibility that even a colorimetric TTI could become a biosensor-type TTI (biosenTTI). Further, information technology (IT) is being applied to monitoring, logistics, and other aspects of food distribution systems $[20,21]$. The use of biosenTTI devices could be extended to IT-based food package logistics.

A biosensor is an analytical device with a bio-recognition element that converts the biological response into a measurable signal, often electrical, which may provide direct information. The development of various classes of biosensors based on different operating principles electrochemical (amperometric, potentiometric) [22], optical [23], piezoelectric [24], and others [25,26] has allowed their application for analyzing a wide range of substances. Even though biosensor technology was developed almost 60 years ago, there are several applications that are still to be studied. The application of biosensor technology to TTI is an example [27]. described a TTI based on an amperometric glucose oxidase (GOx) biosensor that was the first and, until now, the only one studied in the field of biosenTTI. This is a specialized TTI: a lethality indicator appropriate for use in food sterilization, rather than general food package storage or distribution. This TTI was evaluated for the kinetics of thermal inactivation of the immobilized enzyme under isothermal conditions between 70 and $79.7{ }^{\circ} \mathrm{C}$ as well as current generation in order to evaluate the potential of the proposed biosenTTI for food pasteurization processes. However, a biosenTTI for monitoring the quality of chilled foods during storage and transportation has not yet been attempted.

In this study, the GOx biosenTTI used for pasteurization was adapted for use at chilled temperatures. We assumed that the TTI response depends on the temperature sensitivity of the GOx redox reaction in the range of storage or distribution temperatures. The biosenTTI system was composed of a recognition element with GOx, a redox substrate and colorimetric indicator, and a transducing element with a potentiostat. The electrochemistry of the system was analyzed to find the optimum input voltage of the potentiostat. The reaction kinetics and Arrhenius temperature dependency were identified. The electrical signals were also correlated with the TTI color responses.

\section{Materials and Methods}

\subsection{Materials}

Glucose oxidase (EC 1.1.3.4, type X-S from Aspergillus niger, 117200 U/G solid), glucose, methyl red sodium salt and dextrose anhydrous were purchased from Sigma-Aldrich (St. Louis, MO, USA). Deionized ultra-filtered water $(\Omega>18 \mathrm{M} \Omega . \mathrm{cm}$, Fisher scientific, Pittsburgh, PA, USA).

\subsection{Creation of Biosensor-Type TTI}

The TTI was based on a glucose biosensor platform [27]. The TTI system was composed of TTI solution and a potentiostat system (Figure 1). The GOx solution of $0.0015 \mathrm{~g} / \mathrm{mL}$ or $175.8 \mathrm{U} / \mathrm{mL}$ was prepared using $2 \mathrm{mM}$ sodium acetate ( $\mathrm{pH}$ 5.5). The substrate concentration was determined by identifying $\mathrm{K}_{\mathrm{m}}$ value.

$$
\begin{gathered}
V_{0}=V_{\max } \frac{[S]}{[S]+K_{m}}, \\
K_{m}=\frac{k_{-1}+k_{2}}{k_{1}} .
\end{gathered}
$$




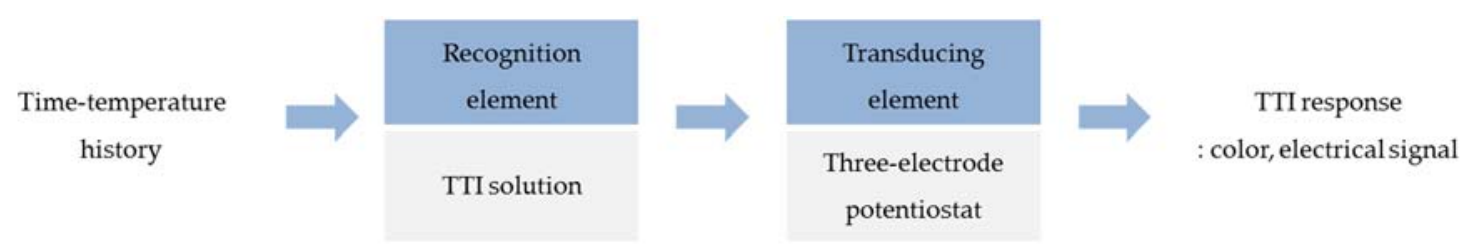

Figure 1. Construction of the biosensor system with time-temperature integrator (TTI) function.

Equation (1) is re-written as the Lineweaver-Burk plot used in regression analysis.

$$
\frac{1}{V_{0}}=\frac{K_{m}}{V_{\max }} \cdot \frac{1}{S}+\frac{1}{V_{\max }} .
$$

To make a final concentration of the substrate solution, a stock glucose solution $(1.0 \mathrm{M})$ was diluted.

The TTI solution was activated by mixing the enzyme solution, substrate solution, and $\mathrm{pH}$ indicator of methyl red sodium salt $(0.0002 \mathrm{~g} / \mathrm{mL})$. Concentrations of the GOx solution were $20 \mu \mathrm{L}$ and $160 \mu \mathrm{L}$, and those of the glucose solution were $3 \mathrm{~mL}$ and $10 \mathrm{~mL}$ for color and electrical signal measurements, respectively.

The potentiostat system (VSP-300, Biologic Science Instruments, Paris, France) was used to measure the TTI electrical signal. Three electrodes (glassy carbon, $\mathrm{Ag} / \mathrm{AgCl}$, and platinum wire) were immersed in the TTI solution contained in a $20 \mathrm{~mL}$ cell vial. Prior to use, the glassy carbon electrode was polished with $0.05 \mu \mathrm{m}$ alumina slurry, followed by washing in deionized ultra-filtered water and allowed to dry at room temperature.

\subsection{Color Measurement of TTI}

The color of the TTI solution was measured by a spectrophotometer (UV-1800 PC, Shimadzu Co., Kyoto, Japan); $3 \mathrm{~mL}$ of the TTI solution was used. The absorbance spectra of the samples were scanned from $400-700 \mathrm{~nm}$ to find the optimal wavelength for measurement. When there was an absorbance saturation, the solution was diluted and the absorbance was corrected according to the dilution ratios.

\subsection{Electrical Signal Measurement of TTI}

A linear sweep voltammogram was first performed in the voltage range of 0.1 to $1.5 \mathrm{~V}$ at the scan rate of $50 \mathrm{mV} / \mathrm{s}$, and an optimal voltage was selected for the current measurement as the electrical signal of TTI.

\subsection{Determination of Kinetic and Arrhenius Parameters of TTI Responses}

The activated TTI solutions $(30 \mathrm{~mL}$ each) were stored in an incubator at different temperatures $\left(5,15,25\right.$, and $\left.35^{\circ} \mathrm{C}\right)$, in beakers covered with plastic film. At certain intervals, the solutions were removed from the incubator and used to measure color change and electrical response. Then, they were returned to the incubator and used for the next measurements.

The rates of color and electrical current changes of TTI were estimated from the data under isothermal conditions. Then, the Arrhenius activation energy $(E a)$ was estimated from the rates.

The color and current variables could be expressed as follows:

$$
\mathrm{Y}=-k t,
$$

where $\mathrm{Y}$ is either the color or current variable, $k$ is the rate constant of reaction or the variable change, and $t$ is the reaction time.

The activation energy (Ea) was calculated by taking the natural logarithm on both sides of the Arrhenius equation.

$$
\ln k=\frac{E \mathrm{a}}{R T}+\ln k_{0}
$$


where $E \mathrm{a}, T, R$, and $k_{0}$ are the Arrhenius activation energy $(\mathrm{kJ} / \mathrm{mol})$, the absolute temperature $(\mathrm{K})$, the gas constant $\left(8.314 \times 10^{-3} \mathrm{~kJ} / \mathrm{mol} \mathrm{K}\right)$, and the pre-exponential factor, respectively.

\subsection{Statistical Analysis}

The color and current measurements were repeated 5 and 3 times, respectively. More repetition on color measurement was due to environmental variables such as light. The averages of color or current were used in linear regression analysis for $k$ estimation [28]. The $k$ was ultimately used in another regression analysis for Ea estimation. Actually, the $k$ from averages and total original values are statistically the same, resulting in the same Ea. A Microsoft Excel program was used.

\section{Results and Discussion}

\subsection{Characterization of BiosenTTI Responses}

Conventional TTI is an indicator, whose response is a color change showing the status of packaged food qualities. The biosenTTI was devised to respond electrically as well as colorimetrically. The mechanism of the biosenTTI is D-gluconic acid and $\mathrm{H}_{2} \mathrm{O}_{2}$ production as a result of a reaction between GOx and $\beta$-D-glucose. As the D-gluconic acid donates $\mathrm{H}^{+}$in the solution, the $\mathrm{pH}$ of the solution drops. This acidic property of D-gluconic acid was used to measure the color development of TTI by using a suitable $\mathrm{pH}$ indicator. This color change reflects the deterioration status of food products.

Figure 2 shows the peaks corresponding to the D-gluconic acid produced by the reaction between GOx and glucose solution with a red sodium salt $\mathrm{pH}$ indicator. Methyl red sodium salt becomes red under $\mathrm{pH} 4.4$ and yellow over $\mathrm{pH}$ 6.2. GOx catalyzes the oxidation of $\beta$-D-glucose to produce one molecule of D-gluconic acid and $\mathrm{H}_{2} \mathrm{O}_{2}$. The product D-gluconic acid dissociates in solution and releases hydrogen ion. Therefore, D-gluconic acid changes the $\mathrm{pH}$ of the solution and consequently changes the color of the entire solution from yellow to red. The wavelength at which maximum absorption was observed, $523 \mathrm{~nm}$, was employed throughout the experiments.

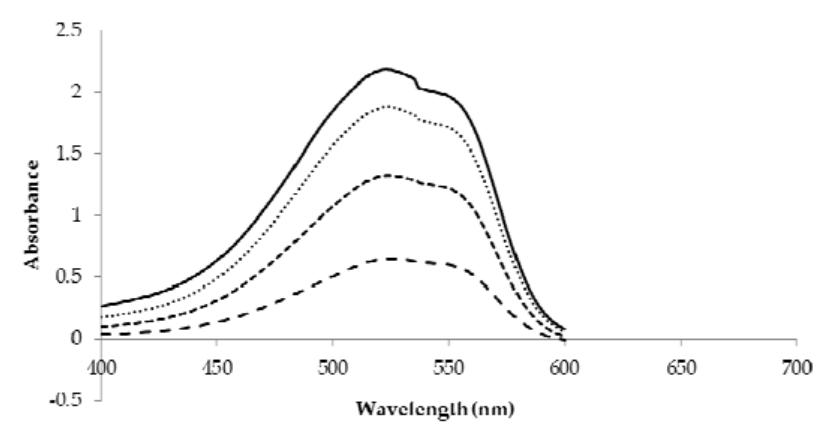

Figure 2. Measured absorption spectra of the TTI solution at different concentrations. "—": measured by $40 \mathrm{mM}$ glucose and GOx, . . : $30 \mathrm{mM}$ glucose and GOx, - - - - : $20 \mathrm{mM}$ glucose and GOx, --- : $10 \mathrm{mM}$ glucose and GOx.

Figure 3 shows the current measured by the linear sweep voltammetric method using a potentiostat, corresponding to the $\mathrm{H}_{2} \mathrm{O}_{2}$ production. In the GOx-catalyzed redox reaction, the reaction is represented by the following reaction equations [29].

$$
\begin{aligned}
& \text { GOx }(\mathrm{FAD})+2 \mathrm{e}^{-}+2 \mathrm{H}^{+} \rightarrow \mathrm{GOx}\left(\mathrm{FADH}_{2}\right), \\
& \mathrm{GOx}\left(\mathrm{FADH}_{2}\right)+\mathrm{O}_{2} \rightarrow \mathrm{GOx}(\mathrm{FAD})+\mathrm{H}_{2} \mathrm{O}_{2},
\end{aligned}
$$

where FAD is flavin adenine dinucleotide. The produced $\mathrm{H}_{2} \mathrm{O}_{2}$ can be electrochemically oxidized to oxygen at a sufficient positive electrode potential at the working electrode of the potentiostat, releasing the electrons and protons that were originally on glucose. In Figure 3, the X-axis represents 
the input voltage, while the Y-axis represents the response of the TTI expressed as current. The current generated at $+1.3 \mathrm{~V}$ was found to change linearly with reaction time at all temperatures. At the other input voltages, the changes were not linear (data not provided in this report), and therefore the voltage of $+1.3 \mathrm{~V}$ was chosen to read the current as TTI responses.

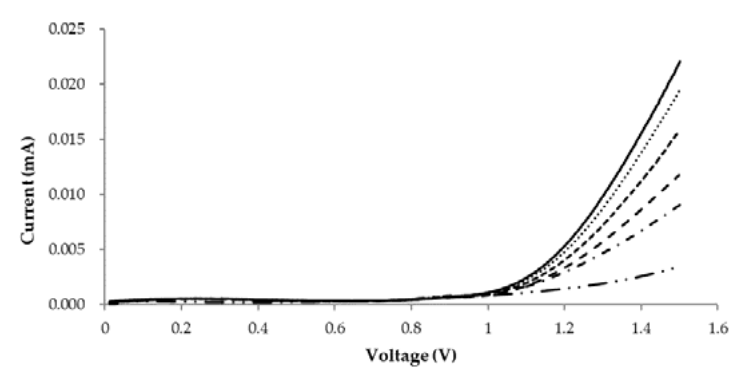

Figure 3. Plot of the current generation against applied potential measured by linear sweep voltammetric method after storage TTI solution at $25{ }^{\circ} \mathrm{C}$ with certain interval time. - : $80 \mathrm{~min}$,

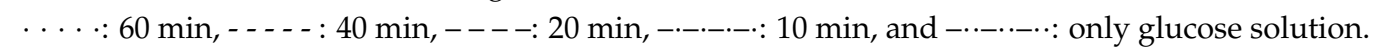

The Michaelis constant, $\mathrm{K}_{\mathrm{m}}$, was evaluated to determine the substrate concentration sufficient to maintain a zero-order reaction. Figure 4 shows the dependence of reaction rate on different concentrations of glucose substrate. From the Lineweaver-Burk plot [30], the $\mathrm{K}_{\mathrm{m}}$ value of GOx was estimated to be $0.86 \mathrm{mM}$, indicating a very high affinity for glucose. The final glucose concentration was determined to be $10 \mathrm{mM}$, ten times higher than the $\mathrm{K}_{\mathrm{m}}$. In order to formulate the TTI composition, the concentration of substrate should be at least 10 times higher than the $K_{m}$ value so that the enzyme is fully saturated by the substrate, consistent with zero-order kinetics [31]. Otherwise, there is a possibility of substrate inhibition and the zero-order kinetics will be transformed to first-order (or a higher order) kinetics; in that case, an estimation of the exact shelf-life of foods would not be possible.
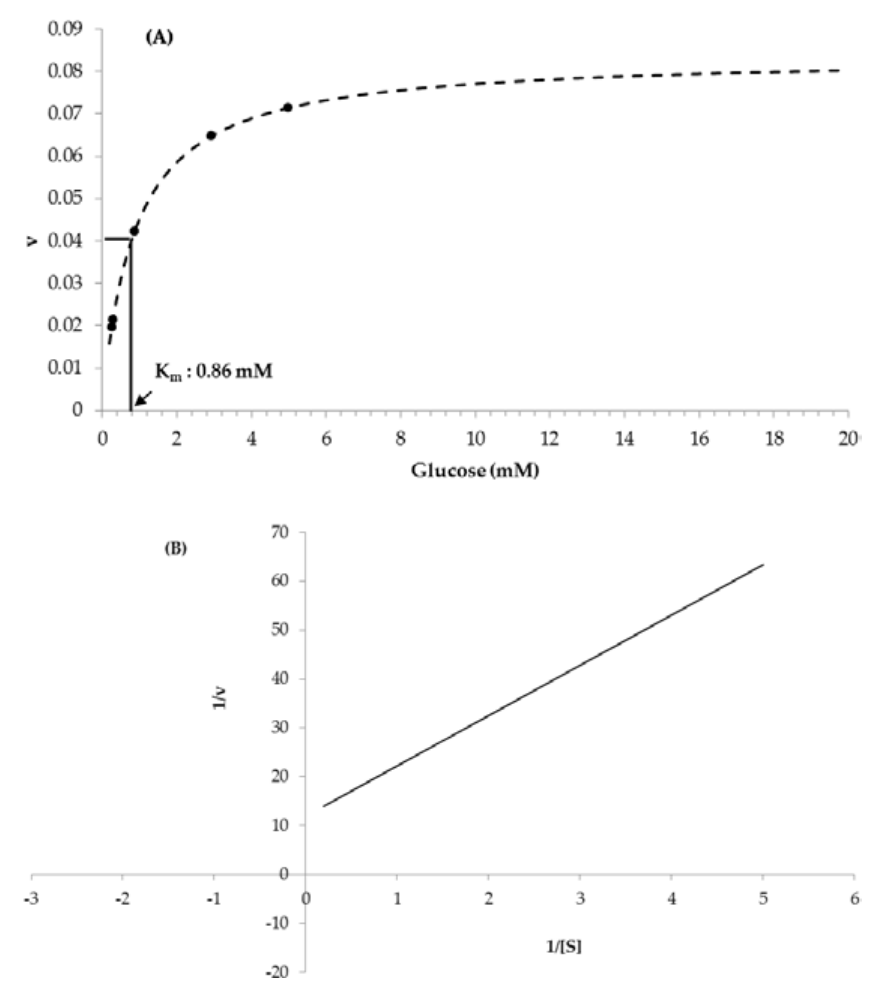

Figure 4. (A) Plot of the reaction velocities against glucose concentrations (mM) and (B) Lineweaver-Burk plot of the experimental data. 


\subsection{Kinetics and Temperature Dependency of BiosenTTI}

The color and the rate of color change increased with the time and temperature, respectively (Figure 5). The color change with time belonged to a zero-order reaction, having high coefficients of determination $\left(\mathrm{R}^{2}\right)$ ranging from $0.98-0.99$ (Table 1 ).

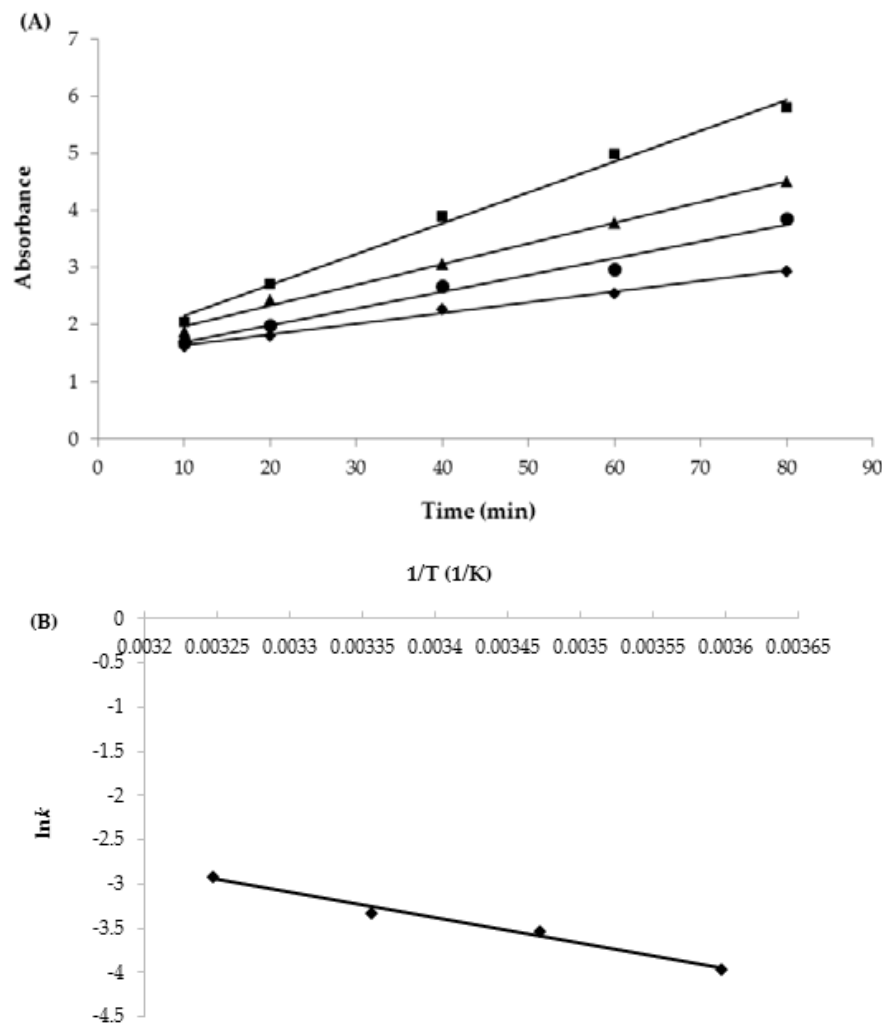

Figure 5. (A) Plot of color change at different isothermal temperatures $\left(\bullet: 5{ }^{\circ} \mathrm{C}, \bullet: 15^{\circ} \mathrm{C}, \mathbf{\Delta}: 25^{\circ} \mathrm{C}\right.$,

口: $35^{\circ} \mathrm{C}$ ) and (B) Arrhenius plot of the reaction rate constants (abs) against temperature.

Table 1. Comparison of reaction kinetics between TTI and TTI biosensor.

\begin{tabular}{ccccc}
\hline Parameters & \multicolumn{2}{c}{ TTI } & \multicolumn{2}{c}{ BiosenTTI } \\
\hline Temperature $\left({ }^{\circ} \mathbf{C}\right)$ & $\boldsymbol{k}(\mathbf{1} / \mathbf{m i n})$ & $\mathbf{R}^{\mathbf{2}} \mathbf{k}(\boldsymbol{\mu} \mathbf{A} / \mathbf{m i n})$ & $\mathbf{R}^{\mathbf{2}}$ \\
\hline 5 & $0.0187 \pm 0.0005^{\text {a }}$ & 0.99 & $0.0360 \pm 0.0020$ & 0.99 \\
15 & $0.0293 \pm 0.0018$ & 0.98 & $0.0566 \pm 0.0026$ & 0.99 \\
25 & $0.0363 \pm 0.0012$ & 0.99 & $0.0716 \pm 0.0024$ & 0.99 \\
35 & $0.0540 \pm 0.0019$ & 0.99 & $0.1073 \pm 0.0028$ & 0.99 \\
\hline
\end{tabular}

${ }^{a}$ True value with $95 \%$ confidence limit in linear regression analysis; ${ }^{b}$ Coefficient of determination.

The zero-order enzyme reactions could be obtained by high concentrations of glucose substrate. If there were not enough glucose, substrate inhibition would lead to an inconsistent reaction order higher than zero. The temperature dependence of the reaction rates affected the Arrhenius relations as well, having an $\mathrm{R}^{2}$ of 0.99 . The Ea $\mathrm{a}_{\text {color }}$ was estimated to be $24.2 \pm 0.6 \mathrm{~kJ} / \mathrm{mol}$. This $E \mathrm{a}_{\text {color }}$ value is too low to monitor the quality of most foods, which have an Ea much higher than this. However, in our previous work using a laccase-based TTI, the Ea of another redox enzyme that was also very low was successfully increased. In a previous study, the Ea was increased and regulated by adding sodium azide, a competitive inhibitor of laccase, or by making a mixture of isoenzymes with a different activation energy [32,33]. Therefore, the low Ea color of the GOx-based TTI could be increased. 
Figure 6 shows the current generated at +1.3 V. The current generation increased linearly with time, indicating a zero-order reaction, and the reaction rates increased with temperature. The reaction rates of the current changes are $0.0360 \pm 0.0020,0.0566 \pm 0.0026,0.0716 \pm 0.0024$, and $0.1073 \pm 0.0028 \mu \mathrm{A} / \mathrm{min}$ at $5,15,25$, and $35{ }^{\circ} \mathrm{C}$, respectively (Table 1 ). The relationship between $\ln k$ against $1 / \mathrm{T}$ was almost linear and $E a_{\text {current }}$ was estimated as $25.0 \pm 1.6 \mathrm{~kJ} / \mathrm{mol}$, having an $\mathrm{R}^{2}$ of 0.99 . This $E \mathrm{a}_{\text {current }}$ is almost the same as that of the color change of TTI $(24.2 \pm 0.6 \mathrm{~kJ} / \mathrm{mol})$. This is because the color change with $\mathrm{pH}$ decrease and the current generation basically arise from the same GOx redox reaction. It has been reported that TTI can be used as a quality indicator when the difference in Ea between the TTI and food is $\pm 20 \mathrm{~kJ} / \mathrm{mol}$ [5]. Therefore, the biosenTTI could be used to monitor the quality of some foods such as frozen pork $(E \mathrm{a}=35.5 \mathrm{~kJ} / \mathrm{mol})$, onions $(E \mathrm{a}=35 \mathrm{~kJ} / \mathrm{mol})$, lettuce $(E \mathrm{a}=37 \mathrm{~kJ} / \mathrm{mol})$, strawberries $(E \mathrm{a}=39 \mathrm{~kJ} / \mathrm{mol})$, etc. [34,35].

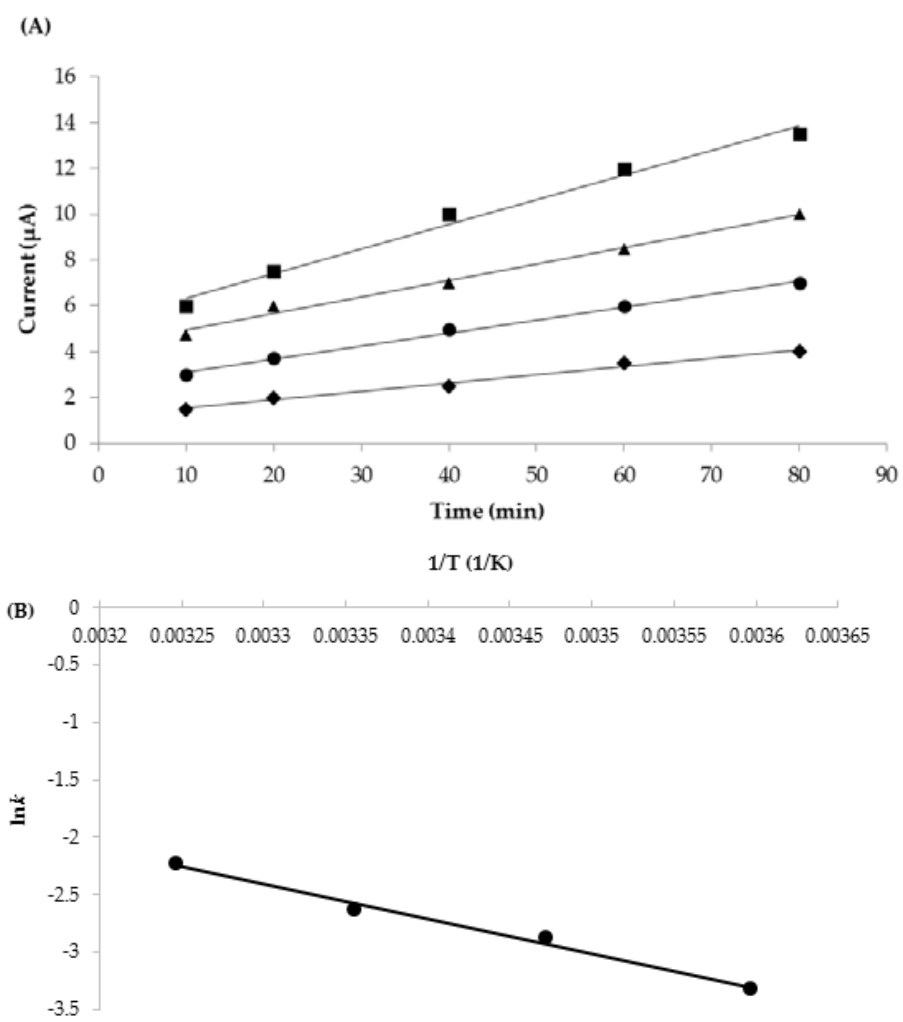

Figure 6. (A) Plot of current generation at different isothermal temperatures $\left(\bullet: 5^{\circ} \mathrm{C}, \boldsymbol{\bullet}: 15^{\circ} \mathrm{C}, \mathbf{\Delta}: 25^{\circ} \mathrm{C}\right.$, 口: $35^{\circ} \mathrm{C}$ ) against time ( $\mathrm{min}$ ) at $+1.3 \mathrm{~V}$ and (B) Arrhenius plot of the reaction rate constants (current) against time.

A linear correlation was observed between the colorimetric and electrical responses of biosenTTI (Figure 7). This is because they commonly followed a zero-order reaction. The correlation coefficient was 0.99 . Consequently, it was confirmed that both the current output and the color changes work well as the TTI responses.

The biosenTTI developed in this study generates a color change and current by a biochemical mechanism at the same time. So, it can be expressed as an electrical signal, rather than simply a visual change, compared with a conventional TTI [12-15]. Although it is still in the early stages of development, biosenTTI has the advantage of directly showing the change in the quality of food as a change, rather than simply integrating time-temperature history, as compared with LCD novel TTI. Unlike temperature data logger, biosenTTI has a function to provide directly the deterioration degree and remaining shelf life of foods other than time-temperature profile or history. 


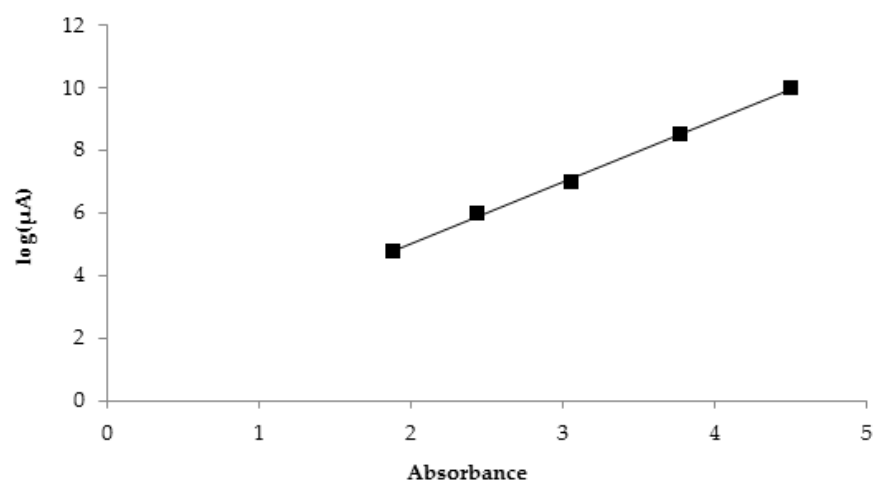

Figure 7. Correlation between the color change (abs) at $523 \mathrm{~nm}$ and the current generation at $+1.3 \mathrm{~V}$ at $25{ }^{\circ} \mathrm{C}$.

TTI is usually used for chilled foods with short-term storage or distribution. As an example, chilled lettuce, an application of TTI, has the total distribution time of $72 \mathrm{~h}$ at the temperature of 3 to $17^{\circ} \mathrm{C}$. It is harvested at $15-17^{\circ} \mathrm{C}$, but it is cooled to $5^{\circ} \mathrm{C}$ in a vacuum refrigerator after $3 \mathrm{~h}$ and then stored in a $5{ }^{\circ} \mathrm{C}$ storehouse for $5 \mathrm{~h}$. The temperature fluctuates in the range from 3 to $15^{\circ} \mathrm{C}$ during shipping. Lettuce is displayed at about $7^{\circ} \mathrm{C}$ in retail stores such as Market [36]. In this case, the stability and performance of biosenTTI were assured because possibly unstable substance in use, GOx, can be stable for 213 days at $4-40{ }^{\circ} \mathrm{C}$ only by adjusting the TTI environments to optimal conditions of $\mathrm{pH}$, enzyme stabilizer, and ionic strength [37].

\section{Conclusions}

Despite the longstanding recognition of TTI as an effective monitoring tool, its commercialization is still in the beginning stages. In this study, we aimed to improve the performance of the traditional form of TTI by integrating its function with a biosensor. Such a biosensor-type TTI could make it possible to provide digital information about food quality instead of analog information, like visible color. Throughout the tests, the GOx-based TTI functioned as a biosensor with significant current changes. This confirms the possibility that a conventional TTI could be transformed into a biosensor. In order to promote this prototype biosenTTI to a practical TTI, further attempts would be needed to adjust the Ea values to the ranges more common in food applications, increase the enzyme stability, and produce the recognition and transducing elements in a test strip and a portable meter.

Author Contributions: Investigation, A.T.M.M.R., D.H.K., H.D.J., J.H.Y., S.J.L.; Writing-original draft, A.T.M.M.R.; Writing-review \& editing, S.J.L.

Funding: This research was supported by R\&D Convergence Center Support Program (710003-03) of the Ministry for Food, Agriculture, Forestry and Fisheries, Republic of Korea.

Conflicts of Interest: The authors declare no conflicts of interest.

\section{References}

1. Browne, M.; Allen, J. Logistics of food transport. In Food Transportation; Heap, R., Kierstan, M., Ford, G., Eds.; Springer: New York, NY, USA, 1998; pp. 22-50.

2. Taoukis, P.S.; Labuza, T.P. Time-temperature indicators (TTIs), In Novel Food Packaging Techniques; Ahvenainen, R., Ed.; Woodhead Publishing: Cambridge, UK, 2003; pp. 103-126.

3. Galagan, Y.; Su, W.F. Fadable ink for time-temperature control of food freshness: novel new time-temperature indicator. Food Res. Int. 2008, 41, 653-657. [CrossRef]

4. Vaikousi, H.; Biliaderis, C.G.; Koutsoumanis, K.P. Applicability of a microbial time temperature indicator (TTI) for monitoring spoilage of modified atmosphere packed minced meat. Int. J. Food Microbiol. 2009, 133, 272-278. [CrossRef] [PubMed] 
5. Taoukis, P.S. Modelling the use of time-temperature indicators in distribution and stock rotation. In Food Process Modelling, 1st ed.; Tijkskens, L.M.M., Hertog, M.L.A.T.M., Nicolaï, B.M., Eds.; Woodhead Publishing: Cambridge, UK, 2001; pp. 402-432.

6. Kang, Y.J.; Kang, J.W.; Choi, J.H.; Park, S.Y.; Rahman, A.T.M.M.; Jung, S.W.; Lee, S.J. A feasibility study of application of laccase-based time-temperature indicator to Kimchi quality control on fermentation process. J. Korean Soc. BioChem. 2014, 57, 819-825. [CrossRef]

7. Giannakourou, M.C.; Taoukis, P.S. Kinetic modeling of vitamin C loss in frozen green vegetables under variable storage conditions. Food Chem. 2003, 83, 33-41. [CrossRef]

8. Giannakourou, M.C.; Koutsoumanis, K.; Nychas, G.J.E.; Taoukis, P.S. Field evaluation of the application of time temperature integrators for monitoring fish quality in the chill chain. Int. J. Food Microbiol. 2005, 102, 323-336. [CrossRef] [PubMed]

9. Nuin, M.; Alfaro, B.; Cruz, Z.; Argarate, N.; George, S.; Le Marc, Y.; Olley, J.; Pin, C. Modelling spoilage of fresh turbot and evaluation of a time-temperature integrator (TTI) label under fluctuating temperature. Int. J. Food Microbiol. 2008, 127, 193-199. [CrossRef] [PubMed]

10. Simpson, R.; Almonacid, S.; Nuñez, H.; Pinto, M.; Abakarov, A.; Teixeira, A. Time temperature indicator to monitor cold chain distribution of fresh salmon (salmo salar). J. Food Process Eng. 2012, 35, 742-750. [CrossRef]

11. Tsironi, T.; Salapa, I.; Taoukis, P.S. Shelf life modelling of osmotically treated chilled gilthead seabream fillets. Innov. Food Sci. Emerg. 2009, 10, 23-31. [CrossRef]

12. Ellouze, M.; Augustin, J.C. Applicability of biological time temperature integrators as quality and safety indicators for meat products. Int. J. Food Microbiol. 2010, 138, 119-129. [CrossRef] [PubMed]

13. Han, J.Y.; Kim, M.J.; Shim, S.D.; Lee, S.J. Application of fuzzy reasoning to prediction of beef sirloin quality using time temperature integrators (TTIs). Food Control 2010, 24, 148-153. [CrossRef]

14. Kim, Y.A.; Jung, S.W.; Park, H.R.; Chung, K.Y.; Lee, S.J. Application of a Prototype of Microbial Time Temperature Indicator (TTI) to the Prediction of Ground Beef Qualities during Storage. Korean J. Food Sci. Anim. Resour. 2012, 32, 448-457. [CrossRef]

15. Bobelyn, E.; Hertog, M.L.A.T.M.; Nicolaï, B.M. Applicability of an enzymatic time temperature integrator as a quality indicator for mushrooms in the distribution chain. Posthavest. Biol. Technol. 2006, 42, 104-114. [CrossRef]

16. Fu, B.; Taoukis, P.S.; Labuza, T.P. Predictive microbiology for monitoring spoilage of dairy products with time-temperature indicators. J. Food Sci. 1991, 56, 1209-1215. [CrossRef]

17. Shellhammer, T.H.; Singh, R.P. Monitoring chemical and microbial changes of cottage cheese using a full-history time-temperature indicator. J. Food Sci. 1991, 56, 402-410. [CrossRef]

18. Claeys, W.L.; Van Loey, A.M.; Hendrickx, M.E. Intrinsic time temperature integrators for heat treatment of milk. Trends Food Sci. Technol. 2002, 13, 293-311. [CrossRef]

19. Dario, D.; Nathalie, G.; Dimitrios, S.; Esther, Z.B.; Paul, T. Active and intelligent food packaging: Legal aspects and safety concern. Trends Food Sci. Technol. 2008, 19, 103-112.

20. Jones, P.; Clarke-Hill, C.; Comfort, D.; Hillier, D.; Shears, P. Radio frequency identification and food retailing in the UK. Br. Food J. 2005, 107, 356-360. [CrossRef]

21. Regattieri, A.; Gamberi, M.; Manzini, R. Traceability of food products: general framework and experimental evidence. J. Food Eng. 2007, 81, 347-356. [CrossRef]

22. Jacob, A.H.; Joseph, W.; Abdel, N.K.; Yun, X.; Kurt, V.G.; Greg, C. Quantum-dot/aptamer-based ultrasensitive multi-analyte electrochemical biosensor. J. Am. Chem. Soc. 2006, 128, 2228-2229.

23. Amanda, J.H.; Richard, P.V. A nanoscale optical biosensor: sensitivity and selectivity of an approach based on the localized surface plasmon resonance spectroscopy of triangular silver nanoparticles. J. Am. Chem. Soc. 2002, 124, 10596-10604.

24. Zhou, X.D.; Liu, L.J.; Hu, M.; Wang, L.L.; Hu, J.M. Detection of hepatitis B virus by piezoelectric biosensor. J. Pharmaceut. Biomed. Anal. 2002, 27, 341-345. [CrossRef]

25. Robert, K.; Anne, M.; Lars, M. Kinetic analysis of monoclonal antibody antigen interactions with a new biosensor based analytical system. J. Immunol. Methods 1991, 145, 229-240.

26. Zhang, Y.; Wen, G.M.; Zhou, Y.H.; Shuang, S.M.; Dong, C.; Choi, M.M.F. Development and analytical application of an uric acid biosensor using an uricase-immobilzed eggshell membrane. Biosen. Bioelectron. 2007, 22, 1791-1797. [CrossRef] [PubMed] 
27. Reyes De Corcuera, J.I.; Cavalieri, R.P.; Powers, J.R.; Kang, D.H. Enzyme electropolymer-based amperometric biosensors: an innovative platform for time-temperature integrators. J. Agric. Food Chem. 2005, 53, 8866-8873. [CrossRef] [PubMed]

28. Sun, Y.; Cai, H.W.; Zheng, L.M.; Ren, F.Z.; Zhang, L.D.; Zhang, H.T. Development and characterization of a new amylase type time-temperature indicator. Food Control 2008, 19, 315-319.

29. Dryhurst, G.; Niki, K. Redox Chemistry and Interfacial Behavior of Biological Molecules; Plenum Press: New York, NY, USA, 1988; pp. 151-171.

30. Lineweaver, H.; Burk, D. The determination of enzyme dissociation constants. J. Am. Chem. Soc. 1934, 56, 658-666. [CrossRef]

31. Bright, H.J.; Porter, D.J. The Enzymes, 3rd ed.; Academic Press: New York, NY, USA, 1975; pp. 421-505.

32. Kim, T.J.; Choi, D.Y.; Yoon, K.H.; Kim, K.H.; Lee, S.J. Application of mixture rule to determine Arrhenius activation energy of time temperature intergrator using mixture of laccase from Pleurotus ostreatus and PEGylated laccase from Trametes versicolor. J. Korean Soc. Appl. Biol. Chem. 2013, 56, 419-425. [CrossRef]

33. Park, H.R.; Kim, K.; Lee, S.J. Adjustment of Arrhenius activation energy of laccase-based time-temperature integrator (TTI) using sodium azide. Food Control 2013, 32, 615-620. [CrossRef]

34. Yoon, S.H.; Lee, C.H.; Kim, D.Y.; Kim, J.W.; Park, K.H. Time-temperature indicator using phospholipid-phospholipase system and application to storage of frozen pork. J. Food Sci. 1994, 59, 490-493. [CrossRef]

35. Pocas, M.F.F.; Delgado, T.F.; Oliveira, F.A.R. Smart packaging technologies for fruits and vegetables. In Smart Packaging Technologies for Fast Moving Consumer Goods; John Wiley and Sons Ltd.: Hoboken, NJ, USA, 2008; pp. 66-151.

36. Koseki, S.; Isobe, S. Prediction of pathogen growth on iceberg lettuce under real temperature history during distribution from farm to table. Int. J. Food. Microbol. 2005, 104, 239-248. [CrossRef] [PubMed]

37. Rando, D.; Kohring, G.W.; Giffhorn, F. Production, purification and characterization of glucose oxidase from a newly isolated strain of penicillium pinophilum. Appl. Microbol. Biotechnol. 1998, 48, 34-40. [CrossRef]

(C) 2018 by the authors. Licensee MDPI, Basel, Switzerland. This article is an open access article distributed under the terms and conditions of the Creative Commons Attribution (CC BY) license (http:/ / creativecommons.org/licenses/by/4.0/). 